\title{
SELF-REGARDING DUTIES AGAIN
}

Prof. Baier maintains that to speak of 'obligations to oneself' is at best "misleading", and furthermore that such putative obligations do not exist inasmuch as "it is no one else's business' whether we do what is best, or right, for us, and at the same time are capable of fulfilling our obligations, moral and non-moral, towards others, without becoming embroiled in a conflict involving incompatible and competing claims. ${ }^{1}$

I respectfully disagree, and for two reasons. (1) J. S. Mill, who in On Liberty more or less single-handedly invented the category of self-regarding duties, nonetheless would agree with Baier that what we do with and to ourselves is no one else's business, insofar as we do not trample on any one else's rights. This does not mean that other people may not be inconvenienced in the process. For instance, if a man gets drunk, and is thereby indisposed to go to work, his employer will be adversely affected. This does not give the employer the right, however, to interfere with his employee's drinking habits. But the concept of self-regarding duty is invoked at this point (by Mill) as an instrument for encouraging the man not to get drunk, for reasons of health, self-respect, or whatever. It takes over where legal obligation, or else moral obligation to others, leaves off, and it tempers (Mill's) insistence on non-interference by "authorities" in "private" matters with an emphasis on moral self-policing and selfeducation, in order to realize one's potential and so make one's life plan, as Baier calls it, rewarding fulfilling. ${ }^{2}$

1 Kurt Baier, "Moral Obligation", American Philosophical Quarterly, Vol. III (1966), p. 225 and $n 27$. For a full discussion of self-regarding duties, see Marcus George Singer, Generalization in Ethics (New York: Alfred A. Knopf, 1961), esp. pp. $311 \mathrm{ff}$.

2 Baier, "Moral Obligation", p. 221. For comprehensive discussions of Mill's theories, see Alan Ryan, John Stuart Mill (New York: Pantheon Books, 1970); John Dewey, Theory of the Moral Life, ed. Arnold Isenberg (New York: Holt, Rinehart and Winston, 1960), pp. 95-101; Singer, Generalization in Ethics, pp. 187 ff., 204 ff.; Maurice Mandelbaum, "On Interpreting Mill's Utilitar ianism". Journal of the History of Philosophy, Vol. VI (1968), pp. 35-46; and 
(2) Baier seems bent on ruling out reflexive cases of obligation altogether, as if they were not genuine relations. If we view obligation as a relation between two parties, $a$ and $b$, what considerations if any compel us to add that $a$ and $b$ are distinct, that is, that $a \neq b$ ? Why not let ' $a=b$ ' be a special case of a more general relationship, $R x y$ ? The problem boils down to one of taxonomy, and as such, as Plato once remarked, is sheerly a matter of preference. ${ }^{3}$ This need not mean that our decisions regarding special cases of obligation need be arbitrary: it depends on what function reflexive (or other) obligation-relations enjoy in a given ethical theory or framework. It is a question of the purposes to which a classification is put, rather than a quasi-metaphysical conundrum as to the "existence" of self-regarding duties; it is the uses, and not the meaning, of the idea which determine whether it should be incorporated into an ethical system or viewpoint, or not.

As long as we are taking one cue from Wittgenstein, we might as well borrow another, to forestall an incipient objection. Baier, following Hart, argues that "obligation" is correctly pinned only on "special situations which exhibit striking resemblances" to presumably clearer-cut cases of legal obligation. ${ }^{4}$ Now, it is true that no one ever signs a contract with himself, but is this an essential characteristics of moral obligation, too, or is it not merely a form of life, that is, a legal custom. And, while a legal agreement between one and the same person would be baffling, because superfluous (who would contest it?), the same thing is not true of ethical obligations to oneself: for instance, standards one simply fails to live up to (which is why there is a tendency to self-impose the obligation in the first place), because of physical inability, conflicting impulses or desires which get the best of us (so-called "moral weakness"), or whatnot. To call self-regarding duties "misleading" betrays a stubbornness: for if the parallel between legal and moral obligation breaks down (as would the attempt to extend either facet to religious obligations), why cling to it at all costs? This is nothing but a foolish consistency.

Language also gives Baier a cold shower. We frequently and legitimately employ such expressions as "I owe it to myself to do suchand-such." If Baier would prefer to redescribe such personal imputa-

John C. Rees, "A Rereading of Mill on Liberty", Political Studies, Vol. VIII (1960), pp. 113-129, reprinted in Peter Radcliffe, ed., Limits of Liberty (Belmont, Calif.: Wadsworth, 1966) pp. 87-106, with a new Postscript (1965), pp. 106-107.

3 Sophist 222B-C.

4 Baier, "Moral Obligation", p. 212. 
tions, he is free to do so: but it is important to note that the insight which self-regarding duty means to convey will then, as it should, be preserved. The wholesale exclusion of self-regarding duties, by that or any other name, would be grossly unfair to certain significant moral considerations which demand a place in the sun. I do not think this is Baier's intention, either, but as he leaves no assurances to the contrary, one cannot help but wonder. Aristotle remarked that while it is difficult to know the Good, it is usually not so hard to determine what is good fur us. If that is so, there is all the more reason not to lay aside self-regarding duties, even if on an adequate account of morality they shuld turn out to have the status of quasi-obligations merely.

DENNIS ANTHONY ROHATYN 